Madrygal. Revista de Estudios Gallegos

ISSN: 1138-9664

\title{
Con Luz Pozo Garza, para sempre ${ }^{1}$
}

Olivia Rodríguez González²

Unha dorna moi livián me leva

velaiño

a alma

xa non podo virar

Non sei se haberá agora neste sufrido mundo un poeta que, con case cen anos, continúe en activo coa forza e a sabedoría con que Luz Pozo Garza seguiu a escribir versos ata o último alento. O seu derradeiro libro de 2018, como os poemas que compuxo despois, seguían a ter o zume fresco da boa poesía. A poesía que ela coñeceu e viviu, desde que empezara a compoñer palabras de luz no Ribadeo natal, onde coincidiu con quen - dicía ela, remontándose ao latín- a inventou: un Dionisio Gamallo Fierros adolescente que lle alquilaba libros e revistas no portal da súa casa e que un día a presentaría como poeta nova a Gerardo Diego. Luz en La Noche de Santiago, Luz en Ínsula e tantas outras revistas, converteuse nunha orixinal creadora en castelán que compartía vida literaria nos parladoiros da Coruña cando acudía á cidade para aprender música. Esa mesma Luz que, xunto cos fermosos libros Ánfora, Cita en el viento, El vagabundo e o decisivo Últimas palabras / Verbas derradeiras, nos que chanta como divisa propia a liberdade e o amor, entrega a súa arte á poesía galega con $O$ paxaro na boca nos difíciles anos 50 e animada por Manuel María. A partir de entón, e coa revista Nordés, capitaneada con Tomás Barros, ábrese como poeta a unha multitude de camiños alumados pola estética simbolista á que sempre foi fiel, cunha voz propia que non deixaría indiferente ás novas xeracións.

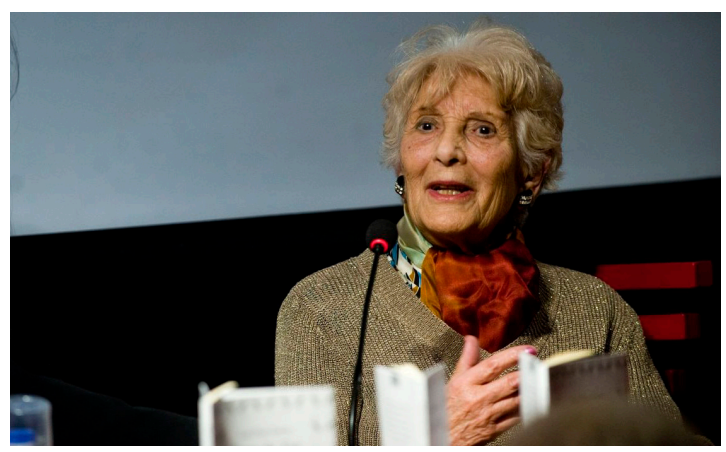

Como catedrática de literatura cultiva o ensaio desvelando claves de Martín Codax, Rosalía de Castro, Luis Pimentel, Luís Seoane, Álvaro Cunqueiro e tantos outros, mesmo Eduardo Moreiras, sempre no seu pensamento. Se Concerto de outono, Códice Calixtino e Prometo a flor de loto significaron a súa consagración, moitos outros títulos amosaron o seu xenio, tan igual e tan distinto no seu devir. Desde a obra completa (2004) Memoria solar, ata Pazo de Tor; pasando por Vida secreta de Rosalía, As arpas de Iwerddon, Medea en Corinto, Vodas palatinas, Sol de medianoche, Deter o día cunha flor, Rosa Tántrica..., a poeta deixa un tesouro que agarda por todos nós. Porque xa se sabe que a mellor homenaxe que se lle pode facer a un escritor é non deixarmos de lelo; e se se trata de poesía, buscarmos nela o que a razón non nos pode explicar.

Publicado primeiramente en La Voz de Galicia o 21 de abril de 2020. Créditos da imaxe: Ángel Manso (La Voz de Galicia 29/06/2019).

2 Universidade da Coruña. Departamento de Letras.

Correo-e: olivia.rodriguez.gonzalez@udc.es. 
Diriamos que o mundo de hoxe, tan raro e difícil, se vai apagar un pouco máis sen Luz. Diríamolo de sermos cincentos. Luz non o quería así. Aprendeunos a ser vitais e alegres con respecto ao futuro. Por iso sabemos que a vida reagromará de novo e con ela medrará a semente poética de Luz Pozo Garza. Quen dixo que a arte era inútil? 